\title{
O QUE PERCEBEMOS QUANDO NÃO VEMOS?^
}

\author{
Joana Belarmino de Sousa ${ }^{\star \star}$
}

\begin{abstract}
Resumo
Este artigo responde a uma questão chave tratada por ocasião do Colóquio "Ver e Não Ver", investigando a natureza da percepção tátil, sobretudo naqueles indivíduos cegos de nascença. O percurso adotado, ainda que dialogue com algumas teorias, opta por uma linguagem mais solta, menos comprometida como rigor científico, trazendo para a discussão, vivências da minha própria infância. Norteia-se por uma concepção chave, explorada em minha tese de doutorado, a qual caracterizei como "mundividência tátil", para explicar um modo tátil de pensarperceber o mundo.
\end{abstract}

Palavras-chave: cegueira; percepção; mundividência tátil.

\section{WHAT DO WE REALIZE WHEN WE DON'T SEE?}

\begin{abstract}
This article answers a key question discussed at the Seminar "To see and not to see", inquiring the nature of tactile perception, specially on born blind people. The argumentation, despite the fact that it is related to some theories, is structured more in an informal language than in a scientific one, bringing to the debate experiences of my own childhood. It is based on a key concept, explored in my PhD thesis, which I defined as "tactile worldseeing" to explain a tactile way of perceiving the world.
\end{abstract}

Keywords: blindness; perception; tactile worldseeing.

\footnotetext{
„Esse artigo é fruto de uma intervenção que fiz por ocasião do Colóquio "Ver e Não-Ver", realizado no Instituto Benjamin Constant, Rio de Janeiro, em outubro de 2008.O trabalho ora publicado, quase não sofreu alteração, a não ser aquelas próprias da formatação, ou pequenos acréscimos que clarificaram melhor algum ponto da comunicação. Manteve-se em todo o texto, o tom coloquial que caracterizou a intervenção e o resultado final exibe apontamentos, pistas para reflexão, trilhas a serem aprofundadas e debatidas no curso de outros trabalhos

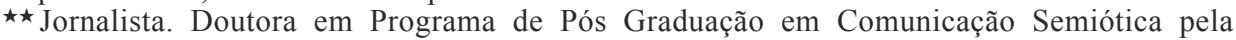
Pontifícia Universidade Católica de São Paulo. Professor titular da Universidade Federal da Paraíba. Endereço: Universidade Federal da Paraíba, Centro de Ciências Humanas Letras e Artes - Campus I, Departamento de Comunicação. Campo Universitário Castelo Branco III. CEP: 58059900 - Joao Pessoa, PB - Brasil.

E-mail: pandora00@uol.com.br
} 


\section{INTRODUÇão}

Eu gostaria de iniciar essa minha comunicação partindo de duas constatações importantes, as quais tiveram impactos profundos no desenvolvimento da visão de mundo dominante na cultura ocidental: A primeira diz respeito ao fato de que a ciência tradicional excluiu ou relegou a um plano inferior os sentidos do olfato e do tato, habilitando o olho e o ouvido como os sentidos prioritários na inquirição do mundo e na produção de conhecimento sobre a realidade.

A segunda constatação diz respeito também ao movimento científico-cultural que não considerou a premissa da diferença, do singular, privilegiando uma racionalidade classificatória, homogeneizante, padronizadora.

Conforme nos diz Restrepo (1998, p. 31):

Frente a uma percepção mediada pelo tato, gosto ou olfato, o Ocidente preferiu o conhecimento dos exteroceptores, ou receptores à distância, como são a vista e o ouvido. Nossa cultura é uma cultura audiovisual. Condicionante tão certo que os Padres da Igreja e o próprio Santo Tomás conceberam o céu como um paraíso visual onde teríamos por toda a eternidade a visão beatífica de Deus, excluindo a possibilidade de um céu táctil, sentido que também haviam censurado na terra.

Assim como a nossa cultura científica relegou o tátil e o olfativo, a lugares inferiores na hierarquia de produção de saber, do mesmo modo abdicou da diferença em favor da homogeneidade, da normalidade, da padronização. Ora, como podemos abdicar da diferença se ela se inscreve como nossa própria assinatura genética no mundo biológico? Cada um de nós contém um arranjo único no modo como nossos genes se multiplicaram, se reduplicaram. Em cada cérebro humano, os arranjos de sinapses e conexões, o modo como se realizam, são únicos para cada indivíduo.

Felizmente, o século XX retoma, em alguns trabalhos, a importância do sentido tátil, sobretudo por via das contribuições das ciências cognitivas e neurolinguísticas, ao mesmo tempo em que correntes filosóficas, psicológicas e fenomenológicas reabilitam a premissa da diferença e a importância de que a mesma seja levada em conta nos processos complexos/plurais.

Da exposição dessas duas constatações, eu gostaria de extrair duas idéias-chave: a idéia da confluência dos sentidos e a da diferença como possibilidades para a construção de um diálogo rico e consequente entre o código tátil e o código da visualidade.

O que percebemos quando não vemos? Queria contemplar essa questão partindo de um caminho que, em princípio, parece não ter nada a ver com o caminho acadêmico-científico. Queria pensar nessa questão com o auxílio de concepções como "mistério", "intervalo" e "zona de sombra". 
Gosto dessas concepções vagas, isentas de cientificidade, porque elas me ajudam a repercutir essa questão dentro de mim mesma, no meu nicho particular onde sou pessoa cega e de onde parto para perceber o mundo. Gosto dessas concepções porque elas me conduzem ao lugar da emoção, da afetividade, da poética e da estética, da memória e das recordações.

Por isso, trarei para esse colóquio algumas evocações da infância. Evocações que guardei como verdadeiras relíquias, porque agora sei que elas são fruto de um esforço ainda que rudimentar de compreensão, de percepção, de palpação do mundo por uma criança que nasceu cega, e que, dotada de um aparelho neurosensório motor cujo principal portão perceptivo era a experiência tátil, exercitava a tarefa de perceber/apreender/interpretar/estar nesse mundo.

Antes das evocações, permitam-me breves considerações acerca desse conjunto de conceitos que eu chamei de "mistério", "intervalo", "zona de sombra".

Não é curioso que o que mais nos impressiona, o que mais nos fascina, o que mais nos instiga, são as coisas, os fenômenos, tudo aquilo que não podemos ver? Fenômenos, coisas, teorias, que parecem estar envoltos em uma zona de mistério, um intervalo de incomunicação, um lugar de sombra?

A nossa cultura, o nosso planeta, o nosso universo não está pleno de coisas que não podemos tocar, nem ver? Nossas ciências, nossa religião, nossa arte, não intentam, ao longo da cultura, construir verdadeiros edifícios ideais para tratar dessas naturezas misteriosas e, principalmente a partir do século XX, aparatos tecnológicos que nos permitam sondar esses fenômenos até então inalcançáveis?

Curiosamente, o desvelamento do mundo parece nos desafiar com o mistério, com o intervalo entre o conhecido e o não conhecido, uma zona de sombra onde fica sempre um resíduo a ser comunicado, interpretado, explicado. Uma zona de "não vidência" que anima e impulsiona a nossa experiência de conhecer, compreender, interpretar, tocar.

Fiz todo esse percurso para chegar à cegueira. Para pensar a cegueira do mesmo modo como a cultura a pensou. A cegueira como um mistério, uma zona de sombra, um hiato, um intervalo, uma situação de incomunicação.

E não apenas o senso comum pensou a cegueira como um mistério. A ciência também o fez. A ciência cuidou de estabelecer teorias que desapropriavam o sujeito cingido pela condição da cegueira de qualidades como a imaginação, a formulação de imagens, uma percepção adequada de mundo.

A ciência, a arte, a religião, ao longo das nossas tradições culturais, mergulharam este sujeito cingido pela condição da cegueira em uma permanente "noite de trevas", em um lugar de sombra, de silêncio e de mistério.

Entretanto, em todo o mundo, ao longo da cultura humana, a pessoa cega esteve de braços dados com a questão que esse colóquio agora traz para debate. Ao longo da cultura, nós realmente nos perguntamos: O que percebemos quando não vemos? 
Mesmo agora, com nosso corpo, com nossas mãos, com nossos olhos abertos ou fechados à brisa da manhã, mesmo agora nos perguntamos sobre o que percebemos quando não vemos.

Eu me pergunto sobre isso desde sempre. Por isso, resgato essas duas evocações da minha infância, ambas muito significativas, ambas plenas da minha fala interior sobre essa questão.

\section{A lição das pedras}

Eu tinha quatro anos quando, numa manhã, me defrontei duramente com o ver e o não-ver. Foi uma experiência difícil. Uma criança que nasceu cega, aos quatro anos, provavelmente, de forma muito íntima, introjetou a idéia de que é uma criança cega, face aos gestos, às verbalizações da família. Mas essa criança ainda não compreende a diferença entre o ver e o não-ver.

Naquela manhã, eu estava brincando no pátio da minha casa, onde havia uma fileira de pedras perto da parede da cozinha, todas pouco menores que eu.

E, de repente, eu dei pela presença das pedras, sem as tocar. Senti a presença delas na minha face, e fiquei maravilhada com aquilo. E comecei a dançar e a pular diante das pedras, repetindo _ Eu vejo! Eu vejo! E, de repente, um salto maior, a cabeça abaixada, e choquei-me violentamente contra uma pedra, encerrando à dor e à sangue a minha primeira lição de ver.

\section{O DiÁlOGO COM O MISTÉRIO}

Pouco tempo depois, aos cinco anos, talvez, lá estava eu às voltas com a terra, as pedras, às voltas com o mistério. Eu atritava pedaços de pedras, somente para sentir o cheiro daquelas faíscas que elas geravam. Cheiro de fogo diferente, uma espécie de fogo antigo que me ligava ao mistério do princípio do mundo, ao princípio da criação das coisas. Pesava a terra entre as minhas mãos de menina, e me perguntava de que matéria ela era feita. Sentia o vento a anunciar a chuva, e me perguntava como chovia, como fazia sol, como ventava.

E o meu cérebro, obediente máquina de pensar, produziu uma resposta para essas minhas indagações. O meu cérebro providenciou para mim um corpo sensível, todo tátil. O meu cérebro inventou uma montanha com sua base rugosa, cheia de arbustos. O meu cérebro fez com que eu escalasse aquela montanha e encontrasse, lá no alto, gavetas que eu podia abrir, para fazer chover, para fazer sol, para fazer ventar.

Tivesse a ciência tradicional tido acesso a essas minhas evocações, tivesse a pedagogia tradicional conhecido, numa sala cheia de crianças da minha idade, que enxergassem, essas minhas rudimentares percepções do mundo, e eu provavelmente seria alvo de um sentimento de compaixão, de piedade, por estar tão longe da verdade. 
Essas reminiscências, porém, exibem a riqueza do universo perceptivo de uma criança cega, brotando do interior de si mesma, ou forjando-se na interação do seu corpo com o ambiente à sua volta.

Na primeira evocação, o que eu vivenciei foi o que poderíamos chamar de percepção cinestésica, ou o que eu chamaria de percepção por proximidade, em que os objetos, aqueles tangíveis ao tato, de acordo com o deslocamento de ar e a sua posição no espaço, em relação a nós próprios, geram uma espécie de sombra, ou o que eu chamo de uma espécie de "presença" que pode comunicar-se principalmente à nossa face.

Na segunda evocação, que eu chamaria de palpação do intangível, o processo brotou do interior. Eu forjei algo parecido com uma espécie de lenda, pondo em curso um processo de fabulação, tão próprio à condição humana, em todas as culturas.

Uma espécie de simbolização, de representação, uma explicação rudimentar para aqueles fenômenos que não são tangíveis ao tato e que, portanto, só podem ser acessados por via da visualidade. Apropriar-se do mundo, a partir de uma montanha que eu pudesse escalar, simbolizava, posso compreender agora, a minha concepção tátil do conceito de grandeza. Criar gavetas que pudessem ser abertas para a chuva, o sol, o vento, era a minha simbolização para o impalpável que eu queria tocar, possuir, guardar, comandar.

Observando a questão por esse prisma, é possível entender que a minha teoria rudimentar não era assim tão pobre. Ela estava plena de uma fala tátil, que na falta da experiência da visualidade, brotava em símbolos de substância, grandeza, altitude, distribuição no espaço, de fenômenos impalpáveis que na minha imaginação eu podia agora comandar.

O perceber, dentro do não-ver, exibe, pois, uma transação. Uma transação permanente entre o corpo, o espaço e os eventos do mundo. O perceber, dentro do não-ver, é um permanente trabalho, envolvendo o contato com a experiência, os fenômenos do mundo, e um aparelho neurosensóriomotor crucialmente dependente de um modo tátil de pensar/perceber, aquilo que em minha pesquisa de doutorado eu chamei de "mundividência tátil"(BELARMINO,2004, p.110) e que, por ocasião da defesa, o professor José Luís Lima aprimorou para "tactognose".

Não vou aqui me alongar falando a respeito do modo tátil de percepção do mundo, embora ressalte que seja de fundamental importância que as escolas dêem voz a esse sujeito cingido pela condição da cegueira, para que ele mesmo possa exibir a sua "fala tátil", uma fala corporal e simbólica, que se estrutura a partir do detalhe, da proximidade, do toque, da cinestesia, esse fenômeno tão complexo e que por si só mereceria muito debate.

Queria falar, sobretudo, da percepção do impalpável, do intangível, do não sensível ao tátil. Eu poderia falar de nuvens e estrelas, ou do encontro mágico do oceano com a linha do horizonte. Poderia falar do pôr-do-sol, tingindo o céu de vermelho vivo, visto do meio do rio, na praia do Jacaré, no meu adorável litoral paraibano. Coisas que, para uma pessoa cega de nascença, estão 
completamente inacessíveis, gerando, em nós, uma espécie de fome de ver, o exercício do cérebro a imaginar, a criar algo, algo que esteja posto no lugar dessa ausência das imagens "reais".

E foi munida com essa "fome de ver", que eu fui buscar alimento para essa percepção do intangível, do impalpável. E estudando a cegueira, percebi que para uma pessoa cega de nascença a percepção do mundo depende crucialmente daquilo que a semiótica chama de "sistemas de corporificação de coisas em texto".

Esses sistemas são a literatura, a arte, a comunicação. É através da literatura que eu vejo corporificado em texto o pôr-do-sol, o céu estrelado, a beleza de um arco-íris.

Mas não precisaria ir tão longe para falar de algo concreto que nos é intangível ao tato. Poderia refletir sobre algo muito mais próximo de nós: a escrita, o livro. Não é curioso que esse dispositivo feito de papel costurado, que diz tudo ao sistema da visualidade, esteja completamente inacessível a uma pessoa cega?

Eu abro um livro, sinto o seu cheiro, toco nas suas páginas e me defronto com um grande oceano branco, uma página lisa e macia.

Isso era verdadeiro até meados do século XIX. Aí veio o Braille, esse grandioso sistema corporificador de escrita visual em escrita tátil.

Seis pontos e suas 63 combinações, e então nosso mundo alargou-se, e nós pudemos tocar o intangível.

O século XXI nos apresenta outro desenvolvimento magistral, conjugando Braille e tecnologia, e criando importantes plataformas de corporificação de coisas em texto.

O perceber, dentro do não-ver, exige, pois, um exercício de mergulho na realidade tátil, pela via da educação, da arte, da psicologia, da cultura, a fim de que se estabeleça a premissa da colaboração, da dialogicidade, da confluência entre os sentidos humanos, para que, então, a lenda pessoal de uma criança cega possa ganhar cada vez mais o enxerto da experiência, da realidade.

\section{REFERÊNCIAS}

BELARMINO, J. Aspectos comunicativos da percepção tátil: a escrita em relevo como mecanismo semiótico da cultura. 2004. Tese (Doutorado)-Programa de Pós-graduação em Comunicação e Semiótica da Pontifícia Universidade Católica de São Paulo, São Paulo, 2004.

RESTREPO, L. C. O direito à ternura. Petrópolis: Vozes, 1998.

Recebido em: abril de 2009

Aceito em: abril de 2009 